were reported to have been admitted. ${ }^{2}$ Numerous newspaper reports suggest that political parties and their student factions have attempted to exploit this intense competition by influencing the admission process in favor of students sympathetic to their cause. A system based on graft is likely to work against students without political connections. Interestingly, most of our respondents report that their fathers' formal education exceeded high school level, which would seem to reflect the small representation of first-generation college students at DU.

\section{Without substantial financial assistance, low-income students simply cannot af- ford quality private higher education in Bangladesh.}

Less than one in five respondents state that they receive some form of financial aid from DU. In the absence of a public system of student loans in Bangladesh, poor students would have little alternative but to seek out such kinds of financing from universities. Traditionally, bright students from low-income families depend on scholarships to attain a public university education. Almost half our sample of students state that they supplement their incomes by working part time. The students report an annual private cost (tuition and fees) incurred during university studies of from $\$ 265$ to as high as $\$ 828$. In a nation where 60 percent of the households live in poverty, public higher education, even when tuition-free, can nevertheless be very expensive. However, these high private costs pale in comparison to the cost of education at a good private university. At North South University, the most popular (but not the most expensive) private university, the annual cost per student exceeds $\$ 3,500$. Without substantial financial assistance, low-income students simply cannot afford quality private higher education in Bangladesh.

\section{Conclusion}

An important selling point for supporting public universities in a developing society is that higher education can be a powerful instrument for building a more equitable society. By providing equal access for good students from the lower social and economic backgrounds, the public university can become a great social and economic equalizer in society. The information obtained from our sample at DU seems to suggest that a majority of students in public universities in Bangladesh come from the relatively affluent section of the urban population. This leads to the disturbing conclusion that the significant public subsidies received by these institutions, far from removing the existing inequities in the society, may be reinforcing these inequities. If these findings are supported by additional empirical evidence, there would indeed be a sound rationale for higher education reform in Bangladesh. Such reform would likely need to include the establishment of a realistic fee structure at public universities, the development of student loans to assist the poor in gaining access to higher education, the creation of special admissions programs for underprivileged youth, and a healthy partnership between public and private universities.

\section{Notes}

I would like to thank S. Basher for research assistance, an anonymous referee for helpful comments, and the AIBS for financial support. The usual disclaimer applies.

1. Muzaffer Ahmad, "Education and Governance in Bangladesh," in Crises in Governance: A Review of Bangladesh's Development, 1997 (Dhaka, Bangladesh: Centre for Policy Dialogue, 1998), 317-32. 2. Zillur Rahman Siddique, Visions and Revisions: Higher Education in Bangladesh, 1947-1992 (Dhaka, Bangladesh: University Press, 1997).

\title{
Challenges for Catholic Higher Education in Japan
}

\section{William Currie, S.J.}

William Currie, S.J. is president of Sophia University, Tokyo, Japan. Address: Sophia University, 7 Kioicho, Chiyoda-ku, Tokyo 102, Japan.

$\mathrm{C}$ atholic universities in Japan, together with all institutions of higher learning in this country (especially the private ones), are facing a difficult year. First, the economic recession continues, which makes it difficult for families to afford tuition for private schooling. Second, the 18-yearold population is shrinking rapidly. Up until now, univer-

sity entrance exams have been a highly competitive affair, and still are to a certain extent, but 10 years from now there will be one university seat available for every eligible 18year-old in the country. Even now, many universities are falling short of their quotas for the entering freshman class.

On top of these problems is a more fundamental one: the whole notion of what a university is supposed to be and do has come up for serious rethinking. A blue-ribbon commission on university reform shook up the educational establishment last year by issuing a call for radical changes in the way universities operate. Since then endless debates have been going on within and without academia, as people seek new directions for university education.

In this last respect, Catholic universities at least have 
an advantage in that they have clear educational goals, an identity, and a founding philosophy that insists on academic excellence. Nevertheless, economic and population factors are having an impact on Catholic higher education, and the next few years are going to be difficult ones.

At present there are 16 Catholic universities in Japan (plus several two-year junior colleges), educating approximately 35,600 students. (Almost one-third of that number, 11,600 students, are studying at Sophia University, the Jesuit university in Tokyo.) Japan as a whole has 98 national universities, 53 public universities, and 425 private universities. Among university students in the country, 73 percent attend private universities. The 16 Catholic universities, like all other private institutions of higher education in this country, are founded and operated by educational corporations established under the supervision of the Ministry of Education. Religious orders and dioceses can affect the management of universities only through the educational corporation, and cannot interfere directly in the running of a university. Freedom of religion is guaranteed, however, as is the right of a university to give religious education.

\section{At present there are 16 Catholic univer- sities in Japan (plus several two-year junior colleges), educating approxi- mately 35,600 students.}

In this context, the Japanese bishops' response to $E x$ Corde Ecclesiae, the 1990 letter of John Paul II, was primarily pastoral, and not particularly threatening to the university community. Since the number of Catholics in Japan is so small (less than half of one percent of the population), the bishops look to the Catholic university community as a principal source of strength in trying to change Japanese society according to the scale of values of the Gospel. The good working relationship between the Japanese hierarchy and the Catholic universities is indicated by the fact that the bishops' response to Pope John Paul's Apostolic Constitution was composed after very extensive consultation and cooperation with representatives of the Japan Association of Catholic University Presidents.

The bishops' statement starts out with an evaluation of Catholic education in Japan, emphasizing the extremely important role it has played in evangelization during the last 130 years, from the time that preaching the Gospel was begun again after being outlawed for 250 years. The bishops go on to speak of the high expectations they have of Catholic higher education in present-day Japanese soci- ety. The document explains the autonomous nature of Japanese universities, founded and operated by educational corporations that are independent and free of outside intervention. Catholic universities are encouraged to make good use of their initiative and independence to look for and hire faculty members with a good understanding of the Catholic spirit, and to carry out a curriculum and educational program that will nourish the Catholic scale of values and worldview. The bishops then claim for Catholic universities the same academic freedom guaranteed by law to all private universities in Japan.

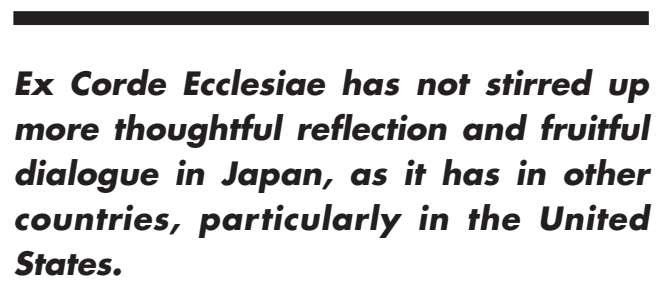

The bishops' statement closes with a description of the responsibilities of the various groups cooperating to help the Catholic university grow and develop: the diocese or religious order that established the educational corporation, the university administrators, the local ordinary, the Bishops' Conference, and the Association of Catholic Universities.

Mention is made that theologians should have a mandate from the competent ecclesiastical authority, but strangely enough, this has not been a source of contention in academic circles in Japan. Already the two largest theology faculties (Sophia's and that of Nanzan, the S.V.D. university in Nagoya) are ecclesiastical faculties requiring approval of teachers from the Congregation for Catholic Education in Rome.

The response to the Japanese bishops from the Congregation for Catholic Education was brief, and requested only minor changes. There was no mention on either side of an oath of fidelity by the president of the university, or any reference to the majority of the trustees being Catholic.

In a way it is perhaps unfortunate that Ex Corde Ecclesiae has not stirred up more thoughtful reflection and fruitful dialogue in Japan, as it has in other countries, particularly in the United States. But Catholic universities in Japan are currently dealing with more basic issues, one of them the problem of how to survive.

\section{Internet Resource}

For more information on issues related to international and comparative higher education, visit the Center's website, located at: http://www.bc.edu/cihe/ 